\title{
Predicting late myocardial recovery and outcomes in the early hours of ST-elevation myocardial infarction: traditional measures compared to microvascular perfusion, salvaged myocardium, and necrosis by cardiovascular magnetic resonance
}

Eric Larose*, Josep Rodés-Cabau, Philippe Pibarot, Stéphane Rinfret, Guy Proulx, Can M Nguyen, Jean-Pierre Déry, Onil Gleeton, Louis Roy, Bernard Noel, Gérald Barbeau, Jacques Rouleau, Jean-Rock Boudreault, Marc Amyot, Robert De Larochellière and Olivier F Bertrand

Address: Quebec Heart Institute at Laval Hospital, Quebec, QC, Canada

* Corresponding author

from 13th Annual SCMR Scientific Sessions

Phoenix, AZ, USA. 21 -24 January 2010

Published: 21 January 2010

Journal of Cardiovascular Magnetic Resonance 20 I0, I2(Suppl I):O77 doi:I0.I I86/1532-429X-12-SI-O77

This abstract is available from: http://jcmr-online.com/content/I2/SI/O77

(c) 2010 Larose et al; licensee BioMed Central Ltd.

\section{Introduction}

Earlier prediction of poor outcomes following ST-elevation myocardial infarction (STEMI) is desirable as it may allow tailored therapy at the earliest possible time when benefits may be greatest and optimized patient orientation in a managed care setting.

\section{Purpose}

Determine whether a very early imaging strategy may improve the prediction of late systolic dysfunction and poor outcomes in STEMI.

\section{Methods}

103 patients with acute STEMI were studied by contrastenhanced cardiovascular magnetic resonance (CE-CMR) within $12 \mathrm{~h}$ of primary angioplasty and after infarct healing at 6 months, and followed clinically beyond 2 years. The primary endpoints were LVEF change and LV dysfunction, while poor outcomes were a key secondary endpoint.

\section{Results}

$37 \%$ of patients with left ventricular dysfunction during STEMI recovered by 6 months, while $27 \%$ of those with compensated systolic function during STEMI developed late LV dysfunction. Late gadolinium enhancement (LGE) volume maintained a stronger association to LVEF change than infarct transmurality, microvascular obstruction, or myocardial salvage during STEMI $(\mathrm{p}=0.02)$. Multivariable logistic regression identified LGE volume during STEMI as the best predictor of late LV dysfunction (OR $1.36, \mathrm{p}=0.03$ adjusted for traditional predictors). An LGE $\geq 30 \%$ of $\mathrm{LV}$ or $18 \mathrm{~mL} / \mathrm{m} 2$ during STEMI correctly classified $89 \%$ of patients for late LV dysfunction. LGE volume during STEMI provided important incremental benefit for predicting late dysfunction (AUC $=0.92$ ) beyond infarct territory, pain-to-balloon time, maximum СКMB rise, presence of $\mathrm{Q}$ waves, and LVEF during STEMI ( $\mathrm{p} \leq 0.03$ for each). Twenty-three patients developed poor outcomes (1 death, 2 myocardial infarctions, 5 malignant arrhythmias requiring AICD, 4 severe LV dysfunction < 35\%, 11 hospitalizations for heart failure) during $2.6 \pm 0.9$ year followup; LGE volume remained a strong independent predictor of poor outcomes, whereas LGE $\geq 30 \%$ or $18 \mathrm{~mL} / \mathrm{m} 2$ carried a hazard ratio of 10.1 for adverse events ( $\mathrm{p}<$ $0.00001)$ Figure 1. 


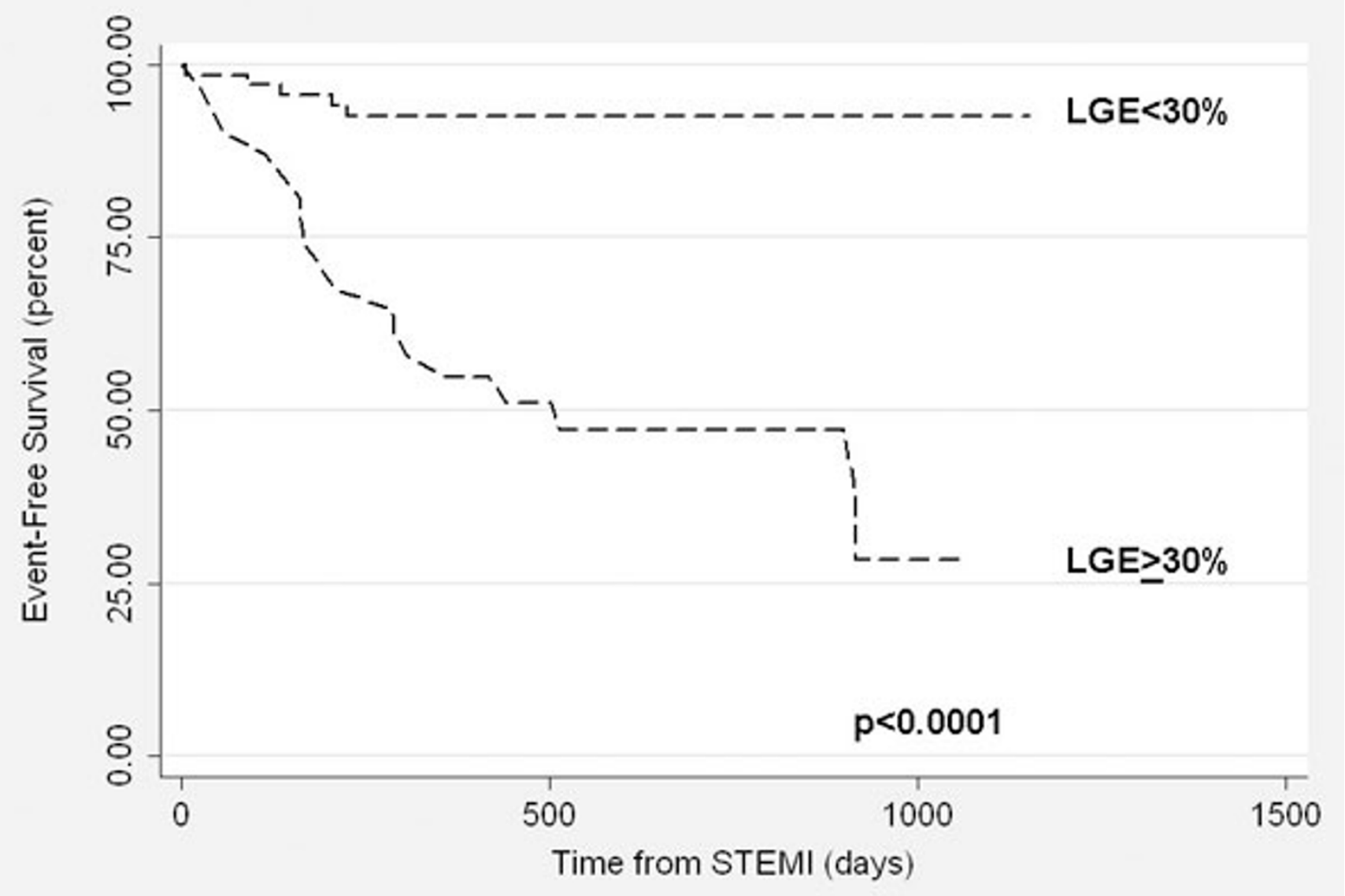

Figure I

\section{Conclusion}

During the hyperacute phase of STEMI, LGE volume provides the strongest association and incremental predictive value for late systolic dysfunction and discerns poor late outcomes. Identifying patients at risk for heart failure or MACE very early during STEMI may allow earlier implementation of prognosis-altering therapies in those likely to benefit most and optimize patient management.
Publish with Biomed Central and every scientist can read your work free of charge

"BioMed Central will be the most significant development for disseminating the results of biomedical research in our lifetime. "

Sir Paul Nurse, Cancer Research UK

Your research papers will be:

- available free of charge to the entire biomedical community

- peer reviewed and published immediately upon acceptance

- cited in PubMed and archived on PubMed Central

- yours - you keep the copyright

Submit your manuscript here:

http://www.biomedcentral.com/info/publishing_adv.asp
BioMedcentral 